\title{
Ethanolic Media Effect on the Susceptibility to Stress Corrosion Cracking in an X-70 Microalloyed Steel with Different Aging Treatments
}

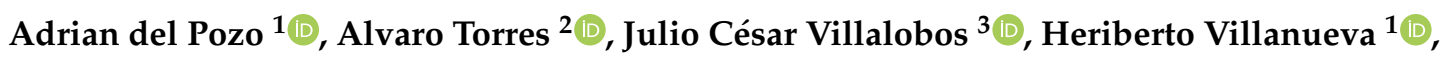 \\ Amilkar Fragiel ${ }^{4}$, Jose Gonzalo Gonzalez Rodriguez ${ }^{1}$ (D) and Sergio Alonso Serna Barquera $1, *$ (D) \\ 1 CIICAp, Universidad Autónoma del Estado de Morelos, Av. Universidad 1001, Col. Chamilpa Cuernavaca, \\ 62209 Morelos, Mexico; adrian.delpozo@alumnos.uaem.mx (A.d.P.); \\ heriberto.villanuevap@uaem.edu.mx (H.V.); ggonzalez@uaem.mx (J.G.G.R.) \\ 2 FCQeI, Universidad Autónoma del Estado de Morelos, Av. Universidad 1001, Col. Chamilpa Cuernavaca, \\ 62209 Morelos, Mexico; alvaro.torres@uaem.mx \\ 3 Departamento de Metal-Mecánica, Ingeniería en Materiales, Tecnológico Nacional de México/Instituto \\ Tecnológico de Morelia, Avenida Tecnológico No. 1500, Col. Lomas de Santiaguito, C.P. 58120 Morelia, \\ Michoacán, Mexico; julio.vb@morelia.tecnm.mx \\ 4 Laboratorio de Física de la Materia Condensada, Centro de Física, Instituto Venezolano de Investigaciones \\ Científicas (IVIC), Apartado 20632, Caracas 1020-A, Venezuela; fragiela@gmail.com \\ * Correspondence: aserna@uaem.mx
}

Received: 15 May 2020; Accepted: 22 June 2020; Published: 25 June 2020

\begin{abstract}
The objective of this research was to evaluate the stress corrosion cracking (SCC) of X-70 micro-alloyed steel in contact with bio-ethanol and E-50 gasohol. Environmental factors, including water $(1 \%, 3 \%$ and $5 \%)$ and $\mathrm{NaCl}(10 \mathrm{mg} / \mathrm{L}$ and $32 \mathrm{mg} / \mathrm{L})$, as well as two aging treatments were studied. Experimental values were obtained by the Slow Strain Rate Test (SSRT) technique, X-ray fluorescence (XRF), and tensile test according to the information reported in the literature. The results of the SSRT for the SCC determination showed that this steel in these conditions did not show evidence of SCC, which was attributed to the formation of an oxide $\left(\mathrm{Fe}_{2} \mathrm{O}_{3}\right)$ not soluble in ethanol. The oxide layer acts as a protector preventing the formation of pitting, one of the main causes of cracks initiation in SCC.
\end{abstract}

Keywords: corn bio-ethanol; microalloyed steel; stress corrosion cracking

\section{Introduction}

The use of fossil fuels plays a major role in climate change due to carbon monoxide emissions. The growth of new technologies solving current and future energy problems has grown in significance, as has the growth of renewable energies including biofuels like bio-ethanol, which has proven to be very useful in reducing greenhouse gases [1-3], has a lower energy yield (close to one-third that of petrol) and has lower vapor pressure, suggesting less evaporative emissions, amongst other things [4]. In recent decades, there has been an increase in the use of bio-ethanol as an alternative to fossil fuels, in efforts to make the transport method more efficient $[5,6]$. Some of the reasons for this increase in the use of bio-ethanol has been the Kyoto protocol and the replacement in the USA of methyl-tert-butyl ether (MBTE) as an octane booster in gasoline, due to its high contaminant potential [7].

The establishment of numerous bio-ethanol production plants by fermentation in several countries has led to an increase in interest for research in the transportation and storage of bio-ethanol and bio-ethanol blends [8]. Currently, bio-ethanol is transported mainly by tank trucks and railway, and the transportation projects in which high-strength and low-alloy steel pipes (HSLA) have been used to increase optimization, reduce costs, and decrease pollutant emissions. These advantages 
are achieved by the advances in metallurgy and manufacturing techniques of HSLA steels such as thermomechanical controlled processing (TMCP) and controlled cooling, which induce an excellent combination of mechanical properties such as high strength and good toughness [9]. The mechanical properties obtained in HSLA steels produced by TMCP are caused by the refinement of the austenite grain size, increase of defects density by deformation, precipitation of microalloying elements such as $\mathrm{Nb}, \mathrm{V}$, and $\mathrm{Ti}$, and the control of phases obtained by post-heat treatments [10]. The increase in mechanical properties allows for the transportation of fuel by pipeline at high pressure with a reduced wall thickness, which reduces the cost of operation and hence the material [11].

A search of the literature revealed few studies that investigate the use of corn bio-ethanol as a substitute fuel. It was found that the bio-ethanol and bio-ethanol blends in contact with some microalloyed steels, zinc-aluminum alloys, carbon steel, castings in fuel pumps, fuel tanks, and welds beside adjacent metal in tank bottoms can exhibit corrosion and stress corrosion cracking (SCC) [12,13]. Few studies found that E-50 bio-ethanol blends have higher SCC susceptibility than in lower or higher bio-ethanol concentration blends [14].

The controversy about the behavior of microalloyed steels in presence of bio-ethanol and its blends has been under constant debate. Mostly, studies have described the roles of water, sodium chloride, acetic acid $\left(\mathrm{CH}_{3} \mathrm{COOH}\right)$, denaturant, methanol, and steel corrosion products [14-16] on SCC. Therefore, the present study sets out to assess the effects of the environmental factors (bio-ethanol concentration, water, and $\mathrm{NaCl}$ ) and metallurgical factors (aging treatments) on SCC of $\mathrm{X}$-70 experimental $\mathrm{Ni}$-microalloyed steel, in order to analyze this steel as a possible candidate for its use in manufacturing of long distance pipes. Previously published work found a higher susceptibility to SCC in carbon steels and microalloyed steels exposed to a mixture of $50 \%$ gasoline and $50 \%$ ethanol (E-50) [17-19]. The novelty in the present work is to focus on the low susceptibility to SCC in different bio-ethanol media of a heat-treated Ni microalloyed steel and to increase its mechanical properties. It was found that the ultimate tensile strength (UTS) was increased as aging time was increased by precipitation hardening, and no cracking was observed on the surface of the Ni-microalloyed steel after being evaluated in different bio-ethanol media. This indicates that this material could be an excellent candidate for use in ethanol transportation.

\section{Materials and Methods}

In the present work an X-70 microalloyed steel was used. Two aging treatments were applied at $30 \mathrm{~min}$ and $1 \mathrm{~h}$ respectively. Both heat treatments were carried out at $600^{\circ} \mathrm{C}$, then let to cool inside the furnace. Figure 1 shows a diagram with the time and the temperature.

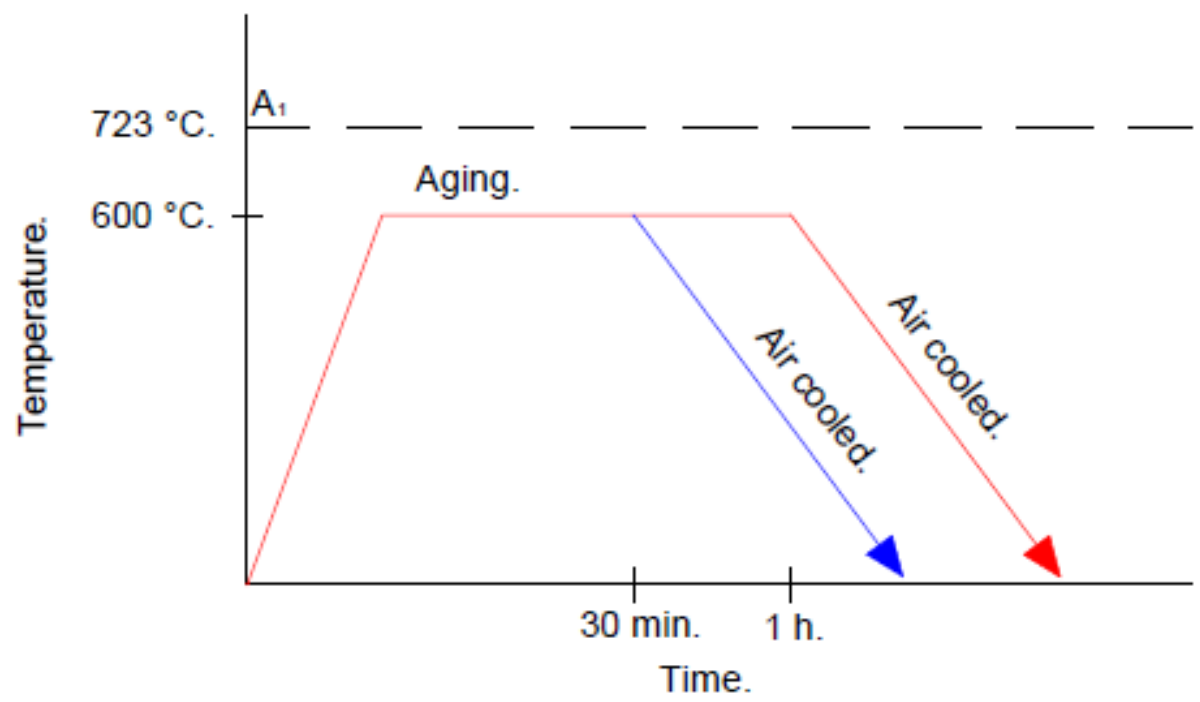

Figure 1. Aging treatments diagram. 
Table 1 shows the corrosive media used in the study.

Table 1. Different corrosive media.

\begin{tabular}{cc}
\hline Corrosive Media & Composition \\
\hline Bio-ethanol & Onli Bio-ethanol \\
\hline E-50 & $50 \%$ Bio-ethanol-50\% Gasoline \\
\hline Modified bio-ethanol & Bio-ethanol with $1 \% \mathrm{H}_{2} \mathrm{O} 10 \mathrm{mg} / \mathrm{L} \mathrm{NaCl}$ \\
\hline Modified bio-ethanol & Bio-ethanol with $3 \% \mathrm{H}_{2} \mathrm{O} 10 \mathrm{mg} / \mathrm{L} \mathrm{NaCl}$ \\
\hline Modified bio-ethanol & Bio-ethanol with $5 \% \mathrm{H}_{2} \mathrm{O} 10 \mathrm{mg} / \mathrm{L} \mathrm{NaCl}$ \\
\hline Modified bio-ethanol & $5 \% \mathrm{H}_{2} \mathrm{O} 32 \mathrm{mg} / \mathrm{L} \mathrm{NaCl}$ \\
\hline
\end{tabular}

\subsection{Chemical Composition}

Table 2 presents the results obtained from spark emission spectroscopy for chemical composition in wt \%. The carbon content is very low $(0.039 \mathrm{wt} \%)$ with $\mathrm{Cr}, \mathrm{Nb}$, Ti and $\mathrm{Al}$ as microalloying elements.

Table 2. Chemical composition of X-70 steel.

\begin{tabular}{cccccccccc}
\hline $\mathbf{C}$ & $\mathbf{S i}$ & $\mathbf{M n}$ & $\mathbf{C r}$ & $\mathbf{M o}$ & $\mathbf{N i}$ & $\mathbf{C u}$ & $\mathbf{N b}$ & $\mathbf{T i}$ & $\mathbf{A l}$ \\
\hline 0.039 & 0.011 & 1.47 & 0.024 & 0.035 & 0.143 & 0.276 & 0.086 & 0.011 & 0.083 \\
\hline
\end{tabular}

\subsection{Microstructural Characterization}

In order to characterize the microstructure of the steel, a metallographic analysis was carried out on $1 \mathrm{~cm} \times 1 \mathrm{~cm} \times 0.6 \mathrm{~cm}$ samples that were polished. The pieces were polished until mirror finished as follows:

1. The steel was sanded progressively with $80,180,280,400,600,800$ and 1000 grit sandpaper.

2. Subsequently, it was polished with $0.5 \mu \mathrm{m}$ alumina and water, until obtaining a surface with a mirror finish.

3. Finally, it ended with an attack on the prepared surface, with $3 \%$ Nital, for $15 \mathrm{~s}$.

\subsection{Tensile Tests}

The tensile test was carried out according to ASTM E8 Standard [20] on a subsize specimen shown in Figure 2 using a physical test solutions machine with a displacement speed of $1 \mathrm{~mm} / \mathrm{min}$. Table 3 lists the specimen parameters.

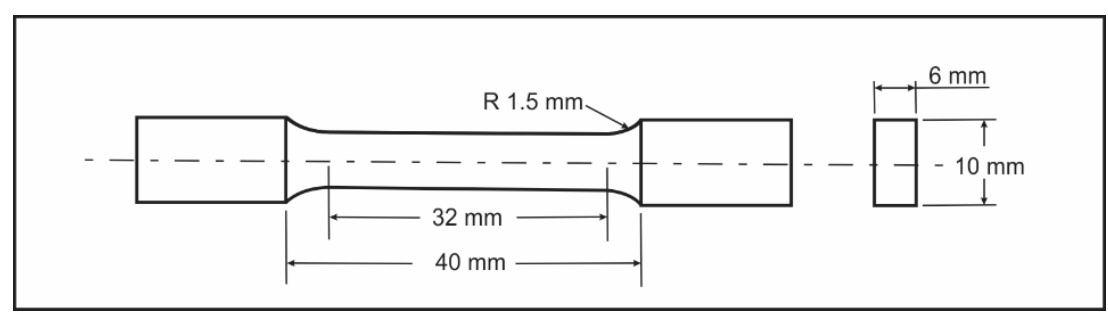

Figure 2. Geometry and dimensions of the tension specimen according to ASTM E8 Standards [20]. 
Table 3. Parameters of the tensile specimens.

\begin{tabular}{cc}
\hline \multicolumn{2}{c}{ Dimensions } \\
\hline Width & $6 \mathrm{~mm}$ \\
\hline Thickness & $6 \mathrm{~mm}$ \\
\hline Radius of fillet & $1.5 \mathrm{~mm}$ \\
\hline Overall length & $100 \mathrm{~mm}$ \\
\hline Length of reduced section & $32 \mathrm{~mm}$ \\
\hline Length of grip section & $30 \mathrm{~mm}$ \\
\hline Width of grip section & $10 \mathrm{~mm}$ \\
\hline
\end{tabular}

\subsection{SSRT}

The SSRTs were carried out using tensile specimens shown in Figure 3 and Table 4 in order to investigate the effect of SCC according to conventional ASTM G129 standard SSRT testing [21]. The strain rate was constant at $1.36 \times 10^{-6} \mathrm{~s}^{-1}$ until fracture according to ASTM G129, with the gauge length section exposed to air or immersed in the media, respectively.

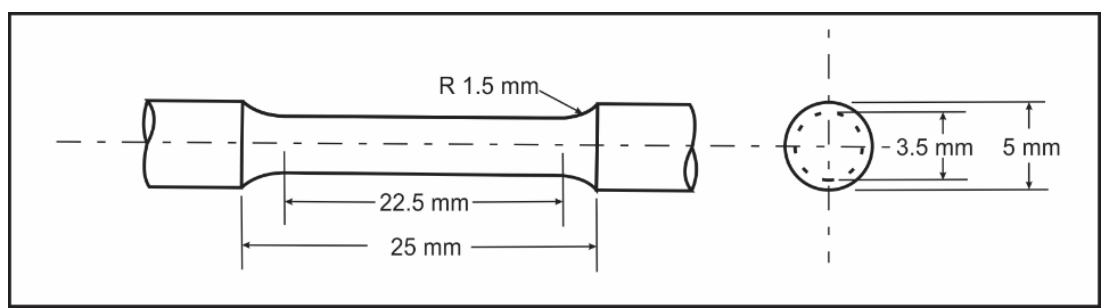

Figure 3. Geometry and dimensions of the tensile specimen for Slow Strain Rate Test (SSRT).

Table 4. Parameters of the SSRT specimens.

\begin{tabular}{cc}
\hline \multicolumn{2}{c}{ Dimensions } \\
\hline Diameter of reduced section & $3.5 \mathrm{~mm}$ \\
\hline Radius of fillet & $1.5 \mathrm{~mm}$ \\
\hline Overall length & $85 \mathrm{~mm}$ \\
\hline Length of reduced section & $22.5 \mathrm{~mm}$ \\
\hline Length of grip section & $30 \mathrm{~mm}$ \\
\hline Diameter of grip section & $5 \mathrm{~mm}$ \\
\hline
\end{tabular}

A $96^{\circ}$ corn bio-ethanol was used as test medium. The gasohol solution was E-50 (50\% bio-ethanol-50\% gasoline 92 octanes). In Figure 4, a schematic of the sealed Nylamid cell employed to contain the gasohol solutions is shown. 


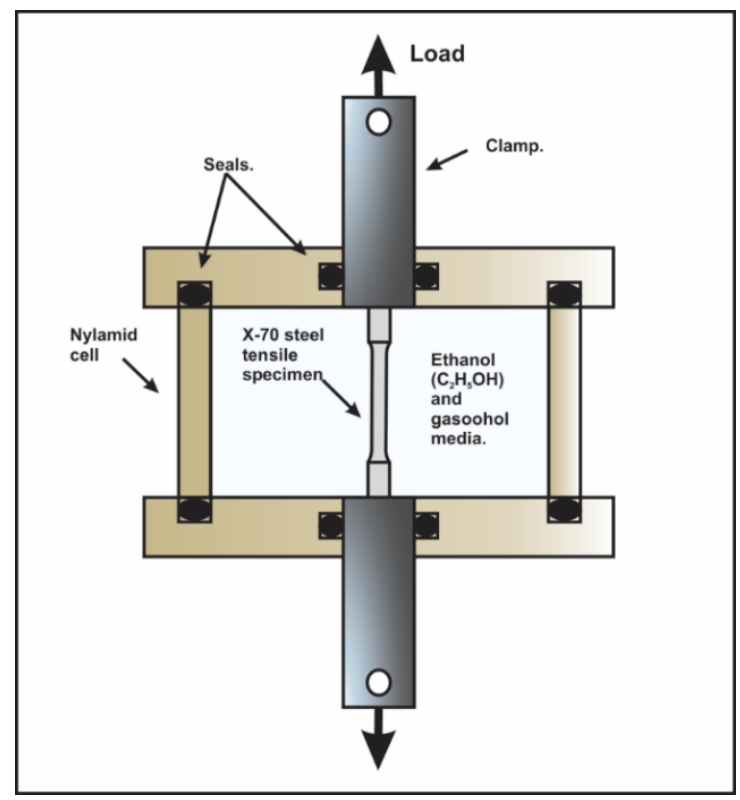

Figure 4. Schematic of the Nylamid cell.

The SSRT specimens were polished longitudinally with a 600-grade silicon carbide sandpaper, degreased, and masked, except for the gauge length. The loss in ductility was assessed in terms of the percentage reduction in area (\%RA) using Equation (1):

$$
\% R A=\frac{A_{i}-A_{f}}{A_{i}} \times 100
$$

where $A_{i}$-Initial area; $A_{f}$-Final area.

\subsection{Fractographic Analysis}

For the purpose of fractographic analysis a scanning electron microscopy (SEM) was used to obtain images of the fracture zone of the SSRT samples.

\subsection{X-ray Fluorescence Spectrometer Analysis}

X-ray fluorescence analyses were carried out on a S8 TIGER 1KW wave-length X-ray fluorescence spectrometer made by Bruker with the following parameters: angle 0.23 degrees, energy $50 \mathrm{KV}$.

\section{Results}

\subsection{Microstructural Characterization}

Figure 5 shows the longitudinal microstructures of the as received steel (a), aged $30 \mathrm{~min}(\mathrm{~b})$ and aged $1 \mathrm{~h}(\mathrm{c})$, where an acicular ferrite matrix was observed with presence of secondary phases of upper bainite [22] in all conditions. Table 5 shows the volume fraction of microalloyed steel in as-received and heat treatment conditions. It was observed that acicular ferrite was found in a slightly larger than the upper bainite in the as-received condition which represented a good combination of mechanical properties described in Section 3.3. However, as aging time increased, the fraction of acicular ferrite increased about $5 \%$ compared with the as-received condition. In general terms, there was not an apparent change in microstructure morphology and the amount of phases remained in the same amount after the steel was heat treated. The ferritic matrix of the as-received steel (Figure 5a) had elongated grains due to the controlled lamination of the low carbon API steel. In the 30 min (Figure 5b) 
and a1-h (Figure 5c) condition a slight change in grain morphology was observed, showing a tendency towards an equiaxiated form.

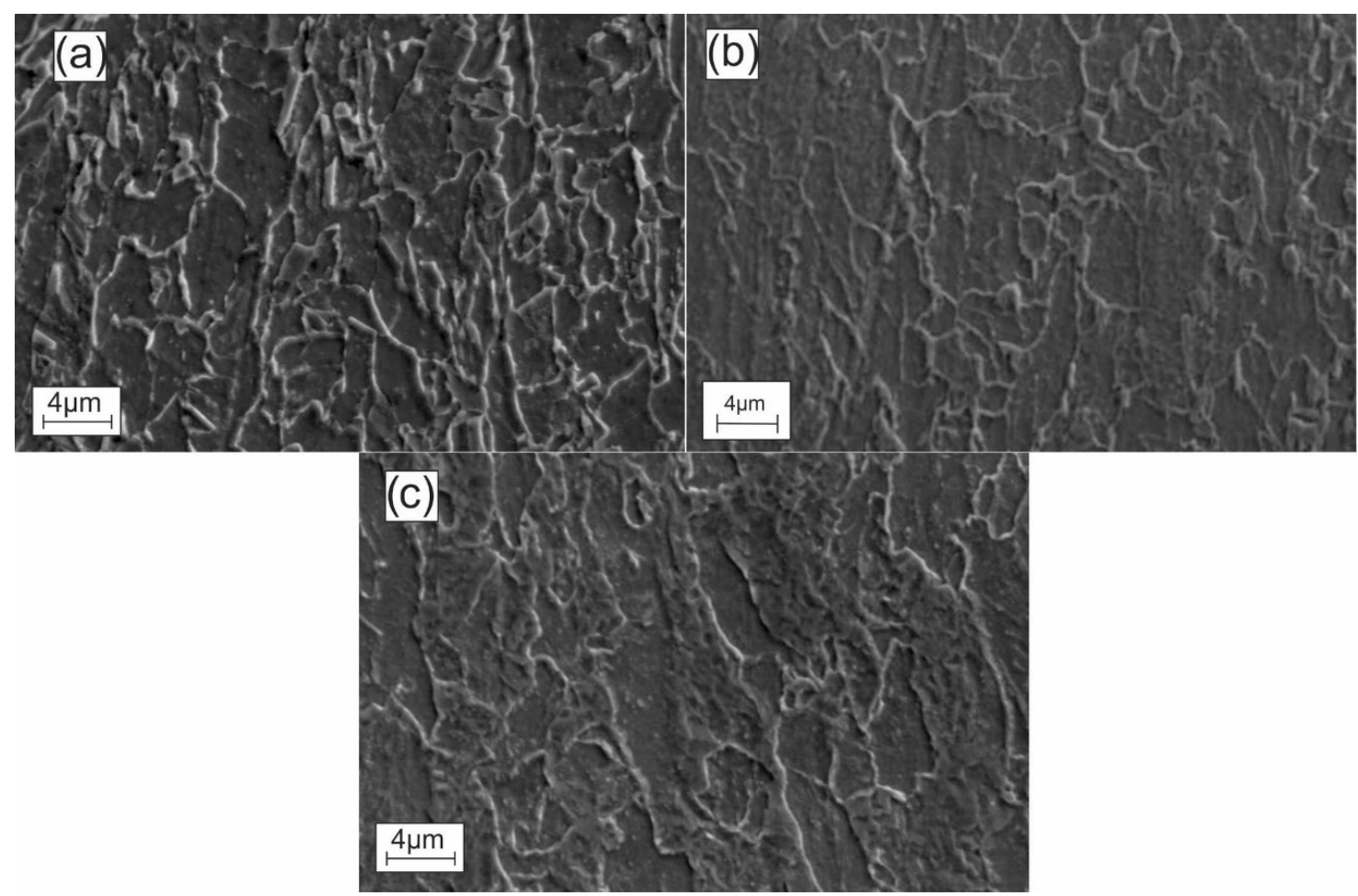

Figure 5. X-70 steel microstructures; (a) as-received, (b) treated at $600{ }^{\circ} \mathrm{C}, 30 \mathrm{~min}$. (c) Treated at $600{ }^{\circ} \mathrm{C}$, $1 \mathrm{~h}$.

Table 5. Acicular ferrite and upper bainite volume fraction of the microalloyed steel in the as-received condition and heat treated.

\begin{tabular}{ccc}
\hline Steel Condition & Acicular Ferrite Fraction (\%) & Upper Bainite Fraction (\%) \\
\hline As-received & 59 & 41 \\
\hline 30 min aged & 64 & 36 \\
\hline 1 h aged & 65 & 35 \\
\hline
\end{tabular}

Figure $6 \mathrm{a}, \mathrm{b}$ show numerous nano-sized carbo-nitrides of $\mathrm{Nb}$ and Ti precipitates distributed into acicular ferrite matrix analyzed by TEM. In contrast to the as-received sample, the aged samples become more homogeneous in structure and a larger number of fine precipitate particles with a size of approximately $10 \mathrm{~nm}$ with small localized zones of precipitate agglomeration found to distribute into the steels matrix. 

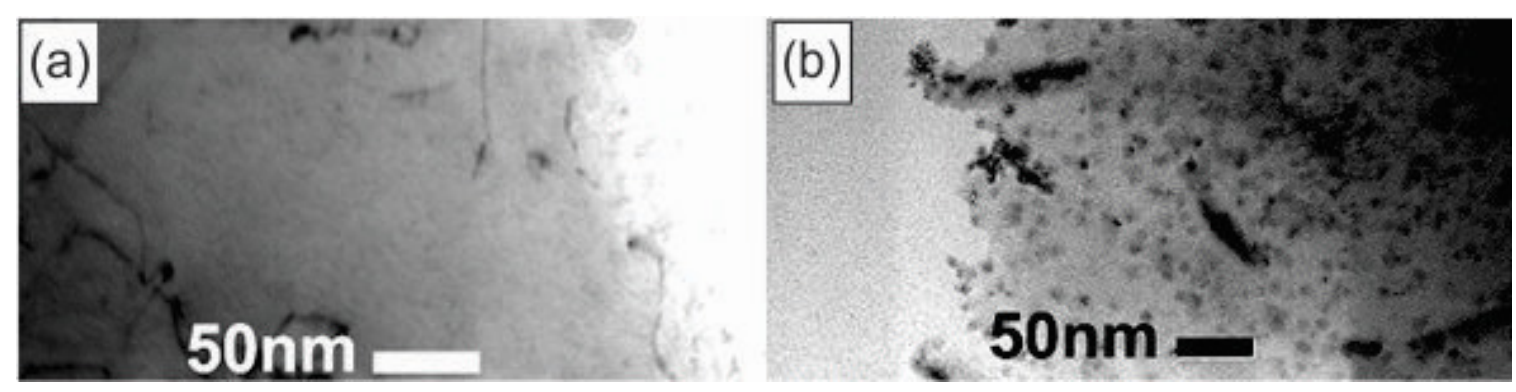

Figure 6. API X70 TEM micrographs: (a) as received pipeline steel TEM micrograph showing precipitation level, (b) $1 \mathrm{~h}$ aged steel specimen showing an increasing number and homogeneous precipitation distribution.

\subsection{Tensile Tests}

Figure 7 shows the strain-stress curves corresponding to the as-received steel, 30 min aged steel, and $1 \mathrm{~h}$ aged steel. Table 6 shows the values of the strain-stress curves. It can be seen that in both cases the heat treatments increased the ultimate tensile strength (UTS), which presented an increase of $4 \%$ for the $30 \mathrm{~min}$ aged steel and 14\% for the $1 \mathrm{~h}$ aged steel with respect to the as-received steel.

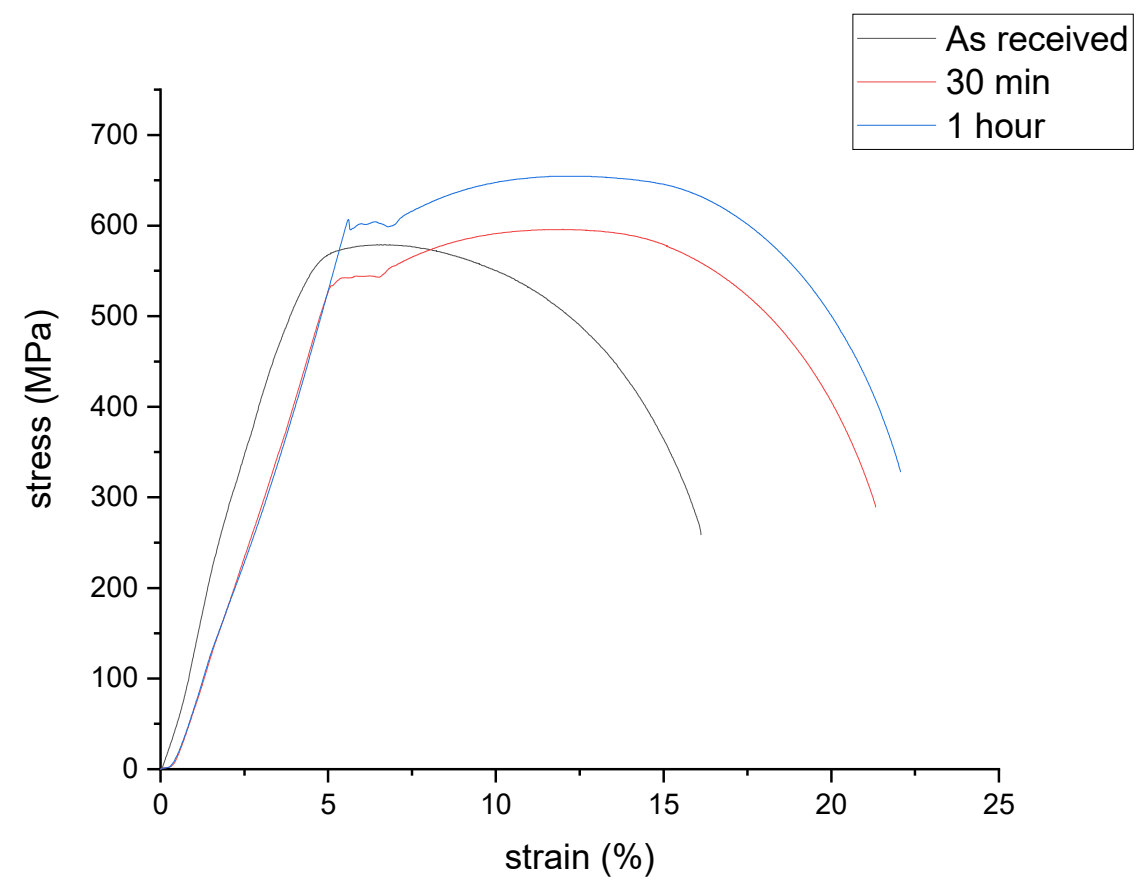

Figure 7. Strain-stress curve for different ageing treatment times of API X-70 steel.

Table 6. Results of the tension test for diffeent ageing treatment times of API X-70 steel.

\begin{tabular}{ccccc}
\hline & $\boldsymbol{\sigma}_{\mathbf{y}} \mathbf{M P a}$ & UTS $\mathbf{M P a}$ & $\boldsymbol{\sigma}_{\mathbf{s}} \mathbf{M P a}$ & $\mathcal{\varepsilon}(\mathbf{\%})$ \\
\hline As received & 541 & 573.3 & 257.6 & 16.1 \\
\hline $30 \mathrm{~min}$. & 543 & 595.833 & 215.972 & 21.43 \\
\hline $1 \mathrm{~h}$ & 600.1 & 654.52 & 247.034 & 22.16 \\
\hline
\end{tabular}

The maximum increase of UTS was presented in the condition of $1 \mathrm{~h}$ aged, with a value of $654 \mathrm{MPa}$, as well as the highest deformation limit, with a value of $22 \%$. Because the heat treatment temperature was below the phase change temperature, the increase in resistance was attributable to precipitation kinetics, where the temperature and time of treatment allowed a possible redistribution 
of niobium and titanium carbonitrides, as well as transition carbides ( $\varepsilon$-carbide), in the same way there was the possibility of a co-precipitation of the micro-alloying elements present in solid solution in the matrix [23,24].

\subsection{Slow Strain Rate Test}

The \%RA was determined for all conditions in order to obtain a measure of the steel embrittlement in contact with bio-ethanol and E-50 gasohol, which is shown in Figure 8 and Table 7.

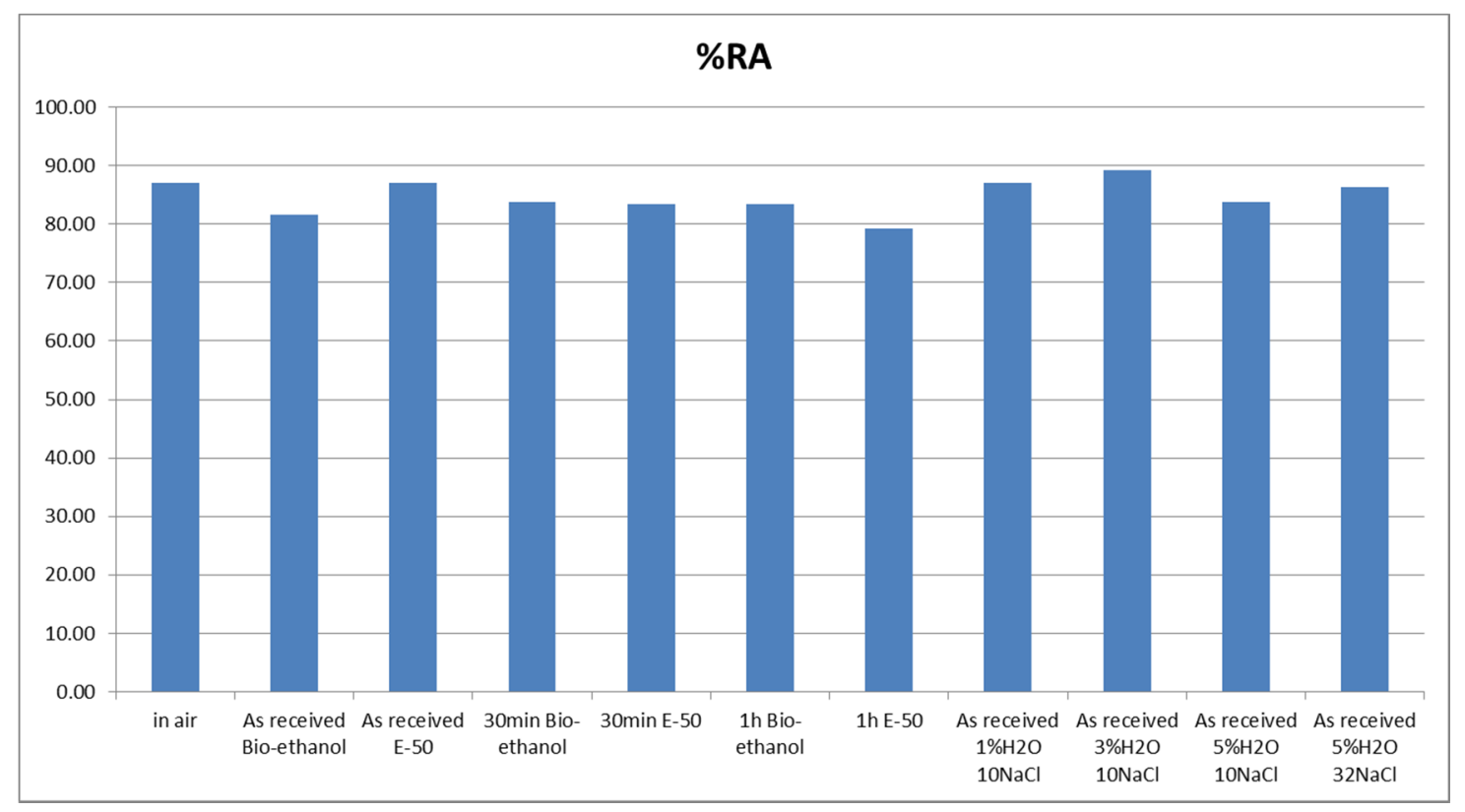

Figure 8. \%RA corresponding to the SSRT.

Table 7. SSRT test results.

\begin{tabular}{cccc}
\hline & $A_{\boldsymbol{i}}(\mathbf{m m})$ & $A_{f}(\mathbf{m m})$ & \%RA \\
\hline As received in air & 9.62 & 1.25 & 87.01 \\
\hline As received bio-ethanol & 9.62 & 1.78 & 81.50 \\
\hline As received E-50 & 9.62 & 1.25 & 87.01 \\
\hline 30 min bio-ethanol & 9.62 & 1.56 & 83.78 \\
\hline 30 min E-50 & 9.62 & 1.6 & 83.37 \\
\hline 1 h bio-ethanol & 9.62 & 1.6 & 83.37 \\
\hline $1 \mathrm{~h} \mathrm{E-50}$ & 9.62 & 2 & 79.21 \\
\hline As received $1 \% \mathrm{H}_{2} \mathrm{O} 10 \mathrm{NaCl}$ & 9.62 & 1.25 & 87.01 \\
\hline As received $3 \% \mathrm{H}_{2} \mathrm{O} 10 \mathrm{NaCl}$ & 9.62 & 1.039 & 89.2 \\
\hline As received $5 \% \mathrm{H}_{2} \mathrm{O} 10 \mathrm{NaCl}$ & 9.62 & 1.56 & 83.78 \\
\hline
\end{tabular}

It can be seen that the specimens showed a ductile type behavior in all conditions, with variations in \%RA less than $7.9 \%$ with respect to the as-received steel in air, which clearly indicated that in these media the presence of SCC was not observed for this particular composition of steel.

Figure 9 shows the fractures of the SSRT specimens in the outer fracture zone for the different test conditions, where a typical morphology of a completely ductile fracture was observed in all conditions, without the presence of cracks. In this type of morphology, the presence of dimples was observed 
which denoted a fracture caused by holes coalescence. Similarly, the presence of crack initiation was not observed. The fractography results presented consistent results with the SSRT tests, which corroborated the absence of SCC.

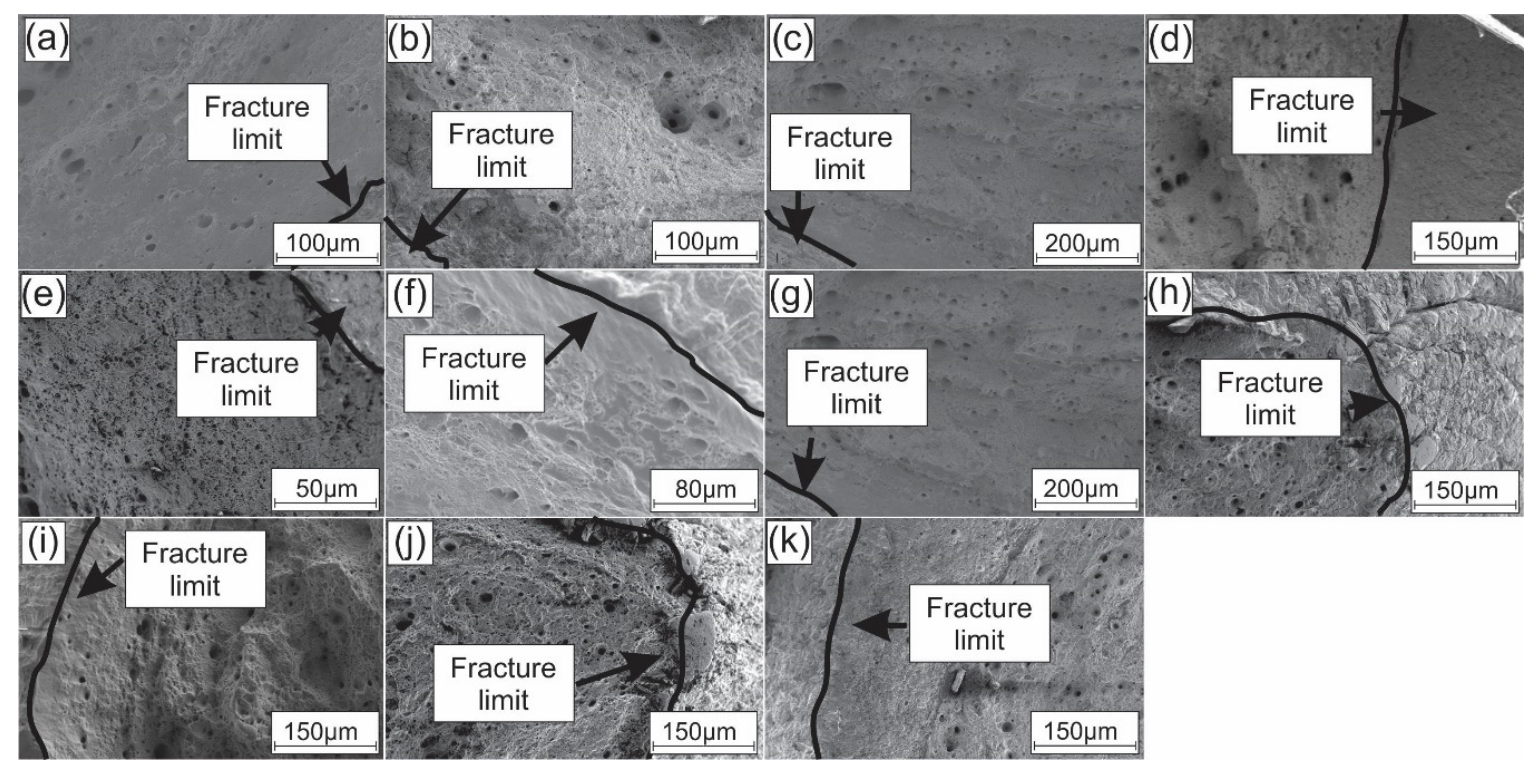

Figure 9. Fractographies of the SSRT tests taken at the edge of the fracture. (a) As-received in air, (b) as-received in bio-ethanol, (c) as-receives in E-50, (d) $30 \mathrm{~min}$ aged in bio-ethanol, (e) $30 \mathrm{~min}$ aged in E-50, (f) $1 \mathrm{~h}$ aged in bio-ethanol, (g) $1 \mathrm{~h}$ aged in E-50, (h) as-received in $1 \% \mathrm{H}_{2} \mathrm{O} 10 \mathrm{NaCl}$ bio-ethanol, (i) as-received in 3\% $\mathrm{H}_{2} \mathrm{O} 10 \mathrm{NaCl}$ bio-ethanol, (j) as-received in 5\% $\mathrm{H} 2 \mathrm{O} 10 \mathrm{NaCl}$ bio-ethanol, (k) As receives $\mathrm{n} 5 \% \mathrm{H}_{2} \mathrm{O} 32 \mathrm{NaCl}$ bio-ethanol.

\subsection{X-ray Fluorescence Spectrometer Analysis}

Table 8 shows the results obtained from the $\mathrm{X}$-ray fluorescence spectrometer analysis in different conditions of bio-ethanol. A clear tendency to present very similar oxide compositions can be observed in all conditions, the most predominant being $\mathrm{Fe}_{2} \mathrm{O}_{3}$ (varying between $79.33 \%$ and $93.06 \%$ ).

Table 8. X-ray fluorescence data.

\begin{tabular}{|c|c|c|c|c|c|c|}
\hline & $\begin{array}{c}1 \% \mathrm{H}_{2} \mathrm{O} \\
10 \mathrm{mg} / \mathrm{L} \\
\mathrm{NaCl}\end{array}$ & $\begin{array}{c}1 \% \mathrm{H}_{2} \mathrm{O} \\
32 \mathrm{mg} / \mathrm{L} \\
\mathrm{NaCl}\end{array}$ & $\begin{array}{c}3 \% \mathrm{H}_{2} \mathrm{O} \\
10 \mathrm{mg} / \mathrm{L} \\
\mathrm{NaCl}\end{array}$ & $\begin{array}{c}3 \% \mathrm{H}_{2} \mathrm{O} \\
32 \mathrm{mg} / \mathrm{L} \\
\mathrm{NaCl}\end{array}$ & $\begin{array}{c}5 \% \mathrm{H}_{2} \mathrm{O} \\
10 \mathrm{mg} / \mathrm{L} \\
\mathrm{NaCl}\end{array}$ & $\begin{array}{c}5 \% \mathrm{H}_{2} \mathrm{O} \\
32 \mathrm{mg} / \mathrm{L} \\
\mathrm{NaCl}\end{array}$ \\
\hline Formula & \multicolumn{6}{|c|}{ Concentration } \\
\hline $\mathrm{Fe}_{2} \mathrm{O}_{3}$ & $86.43 \%$ & $89.39 \%$ & $93.06 \%$ & $79.33 \%$ & $80.38 \%$ & $85.35 \%$ \\
\hline $\mathrm{Na}_{2} \mathrm{O}$ & $4.83 \%$ & $3.80 \%$ & $1.49 \%$ & $9.01 \%$ & $7.55 \%$ & $3.21 \%$ \\
\hline $\mathrm{Cl}$ & $4.72 \%$ & $3.47 \%$ & $1.72 \%$ & $6.30 \%$ & $6.13 \%$ & $5.99 \%$ \\
\hline $\mathrm{P}_{2} \mathrm{O}_{5}$ & $1.29 \%$ & $0 \%$ & $1.25 \%$ & $1.87 \%$ & $1.79 \%$ & $1.96 \%$ \\
\hline $\mathrm{MnO}$ & $1.18 \%$ & $1.26 \%$ & $1.33 \%$ & $1.22 \%$ & $1.31 \%$ & $1.32 \%$ \\
\hline
\end{tabular}

\section{Discussion}

Many investigations have been carried out in microalloyed steels concerning SCC, in which it has been reported that, in bio-ethanol media, two of the main causative compounds are $\mathrm{NaCl}$ and $\mathrm{H}_{2} \mathrm{O}$, which induce crack initiation [25-28] along with points of high stress concentration [29]. An increase in resistance was observed due to aging heat treatment because microalloying elements promote precipitation hardening [30]. The precipitation hardening effect can be increased due to the presence 
of $\mathrm{Ti}$ and Mo in the precipitation of $(\mathrm{Ti}, \mathrm{Mo}) \mathrm{C}$, being smaller and homogeneous they are thermally more stable [31]. On the other hand, the increase in ductility in all conditions is attributed to the change in the morphology of the ferritic grain, which was modified from being elongated due to thermomechanical processing to a little more equiaxiated grain, which softens the matrix, conferring an increase in ductility, in addition to a stress relief in the matrix.

There are studies that have demonstrated the presence of the SCC phenomenon in certain microalloyed steel compositions in different bio-ethanol media, which is attributed the susceptibility of the material to the source of bio-ethanol; corn bio-ethanol is considered a factor that increases susceptibility and cane bio-ethanol shows immunity to SCC [32]. Many authors agree that two of the main factors in crack initiation caused by SCC are water and Cl- [14,15]. SSRT studies were performed to determine the behavior of the SCC during mechanical loading in two ethanolic media (bio-ethanol and E-50), where the as received X-70 steel and both aging treatments showed a very high area reduction, which denoted a high resistance to the SCC phenomenon.

According to the data obtained in the SSRT tests in this study, X-70 steel proved to be immune to SCC in corn bio-ethanol due to the microalloying elements of the steel inhibiting the anodic dissolution by retarding the rupture of the passive layer $[17,18]$, in which no pitting was observed, that was one of the main causes of crack initiation [33]. The tests carried out on bio-ethanol with higher water and $\mathrm{Cl}$ content remained equally immune to SCC, even though these two are the best-known causes of embrittlement SCC factors. Fractographs performed in all conditions did not show evidence of fractures caused by both bio-ethanol media, instead they showed a ductile morphology with a high area reduction and dimples presence, as well as micro-holes coalescence, which are typical in ductile type fractures, which led to a fracture caused by holes coalescence. This was a clear indication that the X-70 steel under study did not show presence of SCC.

There are many types of oxides that can occur in microalloyed steels, and it has been reported that in ethanolic media $\mathrm{Fe}_{2} \mathrm{O}_{3}$ (ferric oxide), $\mathrm{Fe}_{3} \mathrm{O}_{4}$ and iron acetate $\left(\mathrm{Fe}\left(\mathrm{CH}_{3} \mathrm{OO}\right)_{2}\right)$ are the most relevant. These oxides can be soluble or protective in bio-ethanol. Samusawa et al. [19] conducted research on the solubility of iron oxide and iron acetate in bio-ethanol and found that iron acetate is the compound with the highest solubility, and conversely, iron oxides $\mathrm{Fe}_{2} \mathrm{O}_{3}$ and $\mathrm{Fe}_{3} \mathrm{O}_{4}$ are considered ethanol corrosion products with very low solubility, which makes them protective oxides. It was found that the oxide layer formed was likely $\mathrm{Fe}_{2} \mathrm{O}_{3}$, which is known to have a very low dissolution factor in ethanol media, unlike iron acetate $\left(\mathrm{Fe}\left(\mathrm{CH}_{3} \mathrm{OO}\right)_{2}\right)$, which is a corrosion product highly soluble in ethanol (up to 40 times greater than $\mathrm{Fe}_{2} \mathrm{O}_{3}$ ) and its presence has been reported in other microalloyed steels with different chemical compositions [30]. The high resistance to the phenomenon of SCC in bio-ethanol of the API X-70 microalloyed steel is likely related to the formation of a protective oxide $\left(\mathrm{Fe}_{2} \mathrm{O}_{3}\right)$ which retards the anodic dissolution and does not allow pitting. Due to the fact that the anodic solution is connected to the electrochemistry of the steel in contact with the medium. It is necessary to continue with the investigations on this topic, in order to improve the understanding of the phenomenon.

The steel under study presented a very good ethanol SCC resistance, therefore it can be used as material for manufacture of pipes for the transport of ethanol without the need for a coating.

\section{Conclusions}

- The aging treatments increased the UTS in both treatments due to precipitation of microalloying elements.

- The heat treatment increased the ductility in all conditions attributed to the change in the morphology of the ferritic grain and a stress relief in the matrix.

- For this particular steel in these media no presence of SCC was observed.

- The values of \%RA were in a range of 79.21-89.2.

- The oxide layer was found to be primarily $\mathrm{Fe}_{2} \mathrm{O}_{3}$.

- $\mathrm{Fe}_{2} \mathrm{O}_{3}$ retards the anodic dissolution and does not allow pitting. 
- The X-70 microalloyed steel studied is an excellent candidate for its use as a pipe manufacturing material for use in the transport and storage of bio-ethanol.

- To increase the understanding the SCC immunity of this microalloyed steel, further research is required, including an in-depth electrochemical analysis, as well as a more exhaustive analysis of the resulting oxide.

Author Contributions: Conceptualization, S.A.S.B. and A.T.; methodology, A.d.P. and J.C.V.; validation, H.V.; formal analysis, A.d.P.; investigation, A.d.P.; resources, S.A.S.B.; data curation, J.G.G.R. And A.F.; writing—original draft preparation, A.d.P.; writing—review and editing, A.d.P. and J.C.V.; supervision, S.A.S.B.; project administration, S.A.S.B. All authors have read and agreed to the published version of the manuscript.

Funding: This research was funded by CONACyT, grant number 434894.

Acknowledgments: We want to thank René Guardian Tapia and Ivan Puente Lee for the support in providing the SEM images.

Conflicts of Interest: The authors declare no conflicts of interest.

\section{References}

1. Zhang, G.A.; Cheng, Y.F. On the fundamentals of electrochemical corrosion of X65 steel in CO2-containing formation water in the presence of acetic acid in petroleum production. Corros. Sci. 2009, 51, 87-94. [CrossRef]

2. Balat, M.; Balat, H. Recent trends in global production and utilization of bio-ethanol fuel. Appl. Energy 2009, 86, 2273-2282. [CrossRef]

3. Blottnitz, H.; AnnCurran, M. A review of assessments conducted on bio-ethanol as a transportation fuel from a net energy, greenhouse gas, and environmental life cycle perspective. J. Clean. Prod. 2007, 15, 607-619. [CrossRef]

4. Joseph, O.O.; Loto, C.A.; Sivaprasad, S.; Ajayi, J.A.; Tarafder, S. Role of Chloride in the Corrosion and Fracture Behavior of Micro-Alloyed Steel in E80 Simulated Fuel Grade Ethanol Environment. Materials 2016, 9, 463. [CrossRef]

5. Singh, R. Ethanol corrosion in pipelines. Mater. Perform. 2009, 48, 53-55.

6. Sridhar, N. Study examines ethanol pipelines for cracking potential. Mater. Perform. 2007, 46, 18.

7. Canterle, J.O.B.; Moraes, P.M.; Strohaecker, T.R.; Kwietniewski, C.E.F.; Pimenta, G.S.; Baptista, I.P. Evaluation of the Steel API X70 Embrittlement in Different Ethanol Environments. In Proceedings of the Corrosion 2016, Vancouver, BC, Canada, 6-10 March 2016; NACE Intnational: Houston, TX, USA, 2016; pp. 6-10.

8. Reynolds, R.E. Coming to Hawaii-Gasolines Ethanol Blends; Downstream Alternatives Inc.: South Bend, IN, USA, 2007; p. 42.

9. Cuddy, J.L. The effect of Microalloy Concentration on the Recrystallization of Austenite During Hot Deformation. In Thermomechanical Processing of Microalloyed Austenite; AIME: Pittsburgh, PA, USA, 1981; pp. 129-140.

10. Burgmann, F.A.; Xie, Y.; Cairney, J.M.; Ringer, S.P.; Killmore, C.R.; Barbaro, F.J.; Williams, J.G. The effect of niobium additions on ferrite formation in Castrip ${ }^{\circledR}$ steel. Mater. Forum 2008, 32, 9-12.

11. Das, A.K. The Present and the Future of Line Pipe Steels for Petroleum Industry. Mater. Manuf. Processes 2010, 25, 1-3. [CrossRef]

12. Baena, L.M.; Gomez, M.; Calderon, J.A. Aggressiveness of a $20 \%$ Bioethanol- $80 \%$ gasoline mixture on autoparts: I behavior of metallic materials and evaluation of their electrochemical properties. Fuel 2012, 95, 320-328. [CrossRef]

13. API Bulletin 939-E. Identification, Repair and Mitigation of Cracking of Steel Equipment in Ethanol Service, 2nd ed.; API: Washington, DC, USA, 2013.

14. Beavers, J.A.; Gui, F.; Sridhar, N. Effects of environmental and metallurgical factors on the stress corrosion cracking of carbon steel in fuel-grade ethanol. Corrosion 2011, 67, 025005-1-025005-15. [CrossRef]

15. Sridhar, N.; Price, K.; Buckingham, J.; Dante, J. Stress Corrosion Cracking of Carbon Steel in Ethanol. Corros. Eng. 2006, 62, 687-702. [CrossRef] 
16. Gui, F.; Sridhar, N.; Beavers, J.A. Localized Corrosion of Carbon Steel and Its Implications on the Mechanism and Inhibition of Stress Corrosion Cracking in Fuel-Grade Ethanol. Corrosion 2010, 66, 125001-125001-12. [CrossRef]

17. Samusawa, I.; Shiotani, K. Steel Material Having Excellent Alcohol-Induced Pitting Corosion Resistance and Alcohol-Induced SCC Resistance. U.S. Patent 10,532 B2, 2019.

18. Samusawa, I.; Shiotani, K. Development of carbon steel for pipe resistant to stress corrosion cracking in fuel grade Ethanol. In Proceedings of the Corrosion 2016, Vancouver, BC, Canada, 6-10 March 2016; NACE International: Houston, TX, USA, 2016; p. 7173.

19. Samusawa, I.; Shiotani, K. Influence and role of ethanol minor constituents of fuel grade ethanol on corrosion behavior of carbon steel. Corros. Sci. 2015, 90, 266-275. [CrossRef]

20. E 8M Standard Test Methods for Tension Testing of Metallic Materials; ASTM International: West Conshohocken, PA, USA, 2012.

21. ASTM G129-00. Standard Practice for Slow Strain Rate Testing to Evaluate the Susceptibility of Metallic Materials to Environmentally Assisted Cracking; ASTM International: West Conshohocken, PA, USA, 2013.

22. Aaronson, L.; Abraham, H.I.; Adsit, N.R.; Allen, S.M.; Ambalal, P. ASM Handbook Metallography and Microstructures; ASM International: Cleveland, OH, USA, 2004; Volume 9.

23. Ping, Z. Microstructure and mechanical properties in isothermal tempering of high Co-Ni secondary hardening ultrahigh strength steel. J. Iron Steel Res., Int. 2007, 14, 292-295.

24. Park, J.; Lee, Y.K. $\mathrm{Nb}(\mathrm{C}, \mathrm{N})$ precipitation kinetics in the bainite region of a low-carbon Nb-microalloyed steel. Scr. Mater. 2007, 57, 109-112. [CrossRef]

25. Cao, L.; Frankela, G.S.; Sridhar, N. Effect of chloride on stress corrosion cracking susceptibility of carbon steel in simulated fuel grade ethanol. Electrochim. Acta 2013, 104, 255-266. [CrossRef]

26. Youngju, K.; Jaeki, K.; Yooin, J.; Namsub, W.; Sangshik, K. Through-thickness SCC susceptibility of 2024-T351 and 7050-T7451 extrudates in 3.5\% NaCl solution. Metals Mater. Int. 2013, 19, 19-25.

27. Zucchi, F.; Trabanelli, G.; Grassi, V. Stress corrosion cracking of $13 \%$ Cr martensitic steels in sodium chloride solutions in the presence of thiosulphate. Mater. Corros. 2000, 51, 207-212. [CrossRef]

28. Leinonen, H.; Pohjanne, P.; Saukkonen, T.; Schildt, T. Effect of Selective Dissolution on Stress Corrosion Cracking Susceptibility of Austenitic and Duplex Stainless Steels in Alkaline Solutions. In Proceedings of the NACE, Corrosion Conference \& Expo, Houston, TX, USA, 13-17 March 2011.

29. Giorgetti, V.; Santos, E.A.; Marcomini, J.B.; Sordi, V.L. Stress corrosion cracking and fatigue crack growth of an API 5L X70 welded joint in an ethanol environment. Int. J. Press. Vessels Pip. 2019, 169, $223-229$. [CrossRef]

30. Chen, C.Y.; Yen, H.W.; Kao, F.H. Precipitation hardening of high-strength low-alloy steels by nanometer-sized carbides. Mater. Sci. Eng. A 2009, 499, 162-166. [CrossRef]

31. Katsumata, M.; Machida, M.; Kaji, H. Recrystallization of Austenite in High-Temperature Hot-Rolling of Niobium Bearing Steels. In Proceedings of the International Conference on the Thermomechanical Austenite, Pittsburgh, PA, USA, 17-19 August 1981; pp. 17-19.

32. Breitenbach, J.O.; Renck, T.S.; Moraes, P.M.; Kwietniewski, C.E.F.; Strohaecker, T.R.; Pimenta, G.S.; Baptista, I.P. Evaluation of stress corrosion cracking susceptibility of the API 5L X70 steel in corn and sugar cane ethanol environments. In Proceedings of the ASME 34th International Conference on Ocean, Offshore and Arctic Engineering, St. John's, NL, Canada, 31 May-5 June 2015.

33. Lu, B.T.; Chen, Z.K.; Luo, J.L.; Patchett, B.M.; Xu, Z.H. Pitting and stress corrosion cracking behavior in welded austenitic stainless steel. Electrochim. Acta 2005, 50, 1391-1403. [CrossRef]

(C) 2020 by the authors. Licensee MDPI, Basel, Switzerland. This article is an open access article distributed under the terms and conditions of the Creative Commons Attribution (CC BY) license (http://creativecommons.org/licenses/by/4.0/). 